\title{
ANTIGO E
}

NOVO NAS

INTERVENÇÕES

DE CARÁTER

MONUMENTAL

A EXPERIÊNCIA BRASILEIRA (1980-2010)

\section{PATRICIA VICECONTI NAHAS}

Universidade de São Paulo (USP), São Paulo, São Paulo, Brasil

Arquiteta e urbanista pela Universidade Presbiteriana Mackenzie (1998). Mestre em Arquitetura Moderna e Contemporânea com ênfase em intervenções em edificações históricas pela mesma instituição (2009) e doutora em História e Fundamentos da Arquitetura e do Urbanismo pela Universidade de São Paulo (2015), na área de preservação e restauração do patrimônio arquitetônico no Brasil. E-mail: patriciavicecontinahas@gmail.com.

RECEBIDO

02/09/2015

DOI

APROVADO

http://dx.doi.org/10.11606/issn.1980-4466.v0i20p78-111

09/12/2015 


\section{ANTIGO E NOVO NAS INTERVENÇÕES DE CARÁTER MONUMENTAL: A EXPERIÊNCIA BRASILEIRA (1980-2010) PATRICIA VICECONTI NAHAS}

\section{RESUMO}

O artigo vem pautado na reflexão dos recentes diálogos entre antigo e novo, permanência e inovação, preservação e mudança, que fazem parte do cenário da produção arquitetônica contemporânea em que se assiste, cada vez mais, edifícios antigos tornarem-se parte de uma nova história da cidade. Com variadas denominações - restauro, reabilitação, readequação, revitalização, reciclagem -, as ações de intervenção operam sempre com a dimensão do tempo: o tempo de vida do monumento; o tempo durante o qual ele foi submetido à degradação; as sucessivas camadas de tempo que a ele foram acrescentadas pelas transformações por que passou; e o tempo que lhe resta como monumento vivo. A fim de esclarecer essas e outras questões decorrentes dessa abordagem, busca-se investigar como se articulam as premissas teóricas e os critérios de projeto adotados nas intervenções em edifícios de valor histórico e artístico - onde julgamos encontrar-se o cerne do problema - a partir do pensamento italiano de restauro, tendo como base, em especial, os princípios da Carta de Veneza para a análise das características e dos procedimentos utilizados nas intervenções sobre preexistências históricas no Brasil nas últimas décadas. Foram estabelecidas oito tendências de intervenção mais recorrentes em um conjunto de obras analisadas, criando-se grupos com características semelhantes entre si, não totalmente rígidos e fechados, mas que, de alguma forma, pudessem facilitar a leitura das obras e caracterizar o panorama de intervenções no Brasil em relação ao campo disciplinar de restauro.

\section{PALAVRAS-CHAVE}

Patrimônio arquitetônico. Preservação e restauro. Patrimônio 


\title{
THE OLD AND THE NEW IN MONUMENTAL INTERVENTIONS: THE BRAZILIAN EXPERIENCE (1980-2010) PATRICIA VICECONTI NAHAS
}

\begin{abstract}
This article reflects upon the recent dialogue between old and new, permanence and innovation, preservation and change. Aspects that are a part of the contemporary architectural production scenery, where, at increasingly fast pace, old buildings have become part of a new history of the city. Known as restoration, rehabilitation, readjustment, revitalization, recycling, intervention actions always interfere with time: the monument's lifetime, the time during which it was submitted to degradation, the successive layers of time added to it along its transformations and the time it has left as a living monument. To clarify these and other issues on the matter, it is important to investigate the theoretical assumptions and project criteria used by the interventions on buildings of historical and artistic value - where, from my point of view, lies the core of this matter. Our starting point is the Italian school of restoring, specifically the principles of the Venice Charter, to better understand the features and procedures in pre-existing historical interventions in Brazil in the last decades. We have established eight different trends of the most recurrent interventions in a set of analyzed works. The groups formed share features, but we did not use strict criteria, instead they are used to enable the understanding of said works and characterize the range of restoring interventions in Brazil.
\end{abstract}

KEYWORDS

Architectural heritage. Preservation and restoration. Cultural heritage. 
A relação do novo com os edifícios do passado tem se tornado cada vez mais presente na agenda dos arquitetos contemporâneos, onde ações como valorizar o patrimônio, garantir a transmissão do bem cultural para o futuro e dar uma destinação útil ao monumento entram em conflito com o ambiente cultural e a própria projetação do novo.

No panorama de intervenções em monumentos arquitetônicos no Brasil, nos últimos 30 anos, observarmos um fenômeno que Ascención Hernandez Martinez ${ }^{1}$ denomina como o restauro depois do restauro. $\mathrm{Ou}$ seja, as práticas atuais estão se distanciando cada vez mais do que é um restauro de fato e a palavra "restauro" passou a ser usada de forma arbitrária.

Ao avaliar o campo disciplinar do restauro no Brasil em confronto com a produção prática, vemos que é reduzido o número de intervenções que tem como referência os pressupostos da Carta de Veneza, as referências internacionais e o debate atual. O protagonismo do monumento em uma ação de preservação e conservação tem caminhado para um papel de coadjuvante em práticas que procuram dissociar-se do peso que a palavra restauro porta e, assim, justificam-se as ações cada vez mais distantes do campo - sem o correto juízo crítico, cada vez com menos limites em relação à aproximação antigo/

1. Informação pessoal. Conferência "Restauro Trasformazione Riciclaggio. La deriva della disciplina al di là dei criteri consolidati”, Prof. Ascención Hernandez Martinez, Facoltà di Architettura, 'Sapienza' Università di Roma (dezembro/2013). 
novo e com um imenso predomínio da projetação do novo sobre o antigo.

Em seu art. 9, a Carta de Veneza propõe a conceituação de "restauração" como:

uma operação que deve ter caráter excepcional (grifo nosso). Tem por objetivo conservar e revelar valores estéticos e históricos do monumento e fundamenta-se no respeito ao material original e aos documentos autênticos. Termina onde começa a hipótese; no plano das reconstituições conjeturais, todo trabalho complementar reconhecido como indispensável por razões estéticas ou técnicas destacar-se-á da composição arquitetônica e deverá ostentar a marca do nosso tempo. A restauração será sempre precedida e acompanhada de um estudo arqueológico e histórico do monumento. ${ }^{2}$

Excepcional como uma ação de exceção, um ato especial se pensarmos que os monumentos, por princípio, deveriam ser conservados e só em casos extremos restaurados, uma vez que a restauração envolve, mesmo quando de mínima intervenção, a modificação do documento original.

Consideramos que cada obra de arquitetura tem uma realidade particular, uma constituição física, uma história, um determinado valor artístico e está inserida em um ambiente cultural específico, e essa mesma obra - ao adquirir caráter de monumento - é a matéria em que se controlam as escolhas e ações da intervenção que, por sua vez, vão se caracterizar pelo diálogo entre o antigo (o documento original) e o novo (a ações de intervenção) e podem assumir, ou não, um caráter de preservação que as qualifiquem enquanto pertinentes ao campo teórico do restauro.

Partimos da constatação de que a maior parte da produção contemporânea brasileira de intervenções em monumentos se afasta dos critérios prescritos pelo campo disciplinar do restauro, em que a prática dá lugar ao arbítrio e experimentação sem o rigor e juízo crítico pautado na significação

2. INSTITUTO DO PATRIMÔNIO HISTÓRICO E ARTÍSTICO NACIONAL (BRASIL). Cartas patrimoniais. 3. ed. rev. aum. Rio de Janeiro: Iphan, 2004, p. 93. 
da obra preexistente.

A pesquisa é construída pela análise $e^{3}$ de intervenções em edifícios preexistentes com valor histórico e artístico a partir dos pressupostos da Carta de Restauro de Veneza, documento base do International Council on Monuments and Sites (Icomos), criado em 1965 e da qual o Brasil é signatário. Documento redigido no II Congresso Internacional de Arquitetos e Técnicos dos Monumentos Históricos, e fruto das discussões iniciadas no pós-guerra europeu, em especial no território italiano ${ }^{4}$, seus preceitos tiveram como base as questões levantadas pelos promotores do Restauro Crítico e encontram ressonâncias até hoje nas intervenções e estudos dos seguidores do Restauro Crítico-Conservativo.

Adotamos o Restauro Crítico-Conservativo, herdeiro direto do Restauro Crítico e da Teoria da Restauração $0^{5}$ de Cesare Brandi, como referência para a produção arquitetônica mundial por compartilharmos suas premissas e postulados em relação à conservação e intervenção nos monumentos, aproximando a teoria da prática ${ }^{6}$.

Partindo do respeito pelo monumento em sua integridade e autenticidade, em face de uma atitude crítica diante das características estéticas e históricas presentes no monumento, o Restauro Crítico-conservativo propõe

3. Para promover esta reflexão, tomou-se como referência uma série de obras selecionadas, as posturas, as características e os procedimentos que têm direcionado as intervenções em preexistências históricas no Brasil. Cf. NAHAS, Patricia Viceconti Nahas. Antigo e novo nas intervenções em preexistências históricas: a experiência brasileira (1980-2010). 2015. Tese (Doutorado em Arquitetura e Urbanismo) - Faculdade de Arquitetura e Urbanismo da Universidade de São Paulo, São Paulo, 2015. 4. A escolha do cenário italiano de restauro para o embasamento teórico da pesquisa deve-se à sua grande relevância e consolidada tradição em âmbito internacional e constante debate a respeito do tema. Destaca-se aqui: a posição de Gustavo Giovannoni e seu papel na Conferência de Atenas de 1931, na redação da Carta Italiana de Restauro de 1932 e na instituição da disciplina de Restauro dei Monumenti na Scuola di Architettura de Roma; as formulações de Roberto Pane, Piero Gazzola e Renato Bonelli na origem do que se convencionou chamar Restauro Crítico, mais tarde influenciando a formulação da Carta de Veneza; a Teoria da Restauração de Brandi e toda a contextualização do debate face às destruições da Segunda Guerra Mundial, que permitiu a constituição de um campo disciplinar sólido, no qual rigor, método, história e conhecimento da obra antiga colocam o monumento como centro da ação de intervenção.

5. Publicada pela primeira vez em 1963. BRANDI, Cesare. Teoria da restauração. Trad. Beatriz Mugayar Kühl. São Paulo: Ateliê Editorial, 2004.

6. As proposições do Restauro Crítico, associadas às formulações de Cesare Brandi, estão presentes no debate atual do restauro a partir de interpretações e apropriações que ora dão mais ênfase às questões estéticas do monumento, ora à sua estratigrafia histórica. É o que veremos materializado nas práticas dos expoentes da Manutenção-repristino e Pura-conservação, respectivamente. Como ponto de equilíbrio entre essas duas vertentes, buscando o correto juízo entre as instâncias estética e histórica e uma solução apropriada para a intervenção no monumento, seguindo como premissa a conservação e revelação de seus valores para a sua transmissão ao futuro, encontra-se o denominado Restauro Crítico-conservativo, que tem em Giovanni Carbonara seu maior expoente na atualidade. 
uma metodologia válida e atual, fruto de um amadurecimento do debate dos anos 1950 e 1960, em que o projeto de restauro é colocado entre a avaliação dos princípios de intervenção e a partir do juízo crítico da obra e a sua concretização. A criatividade é subsidiada pelo controle e humildade do arquiteto restaurador diante das solicitações atuais para dar continuidade à vida do monumento.

O monumento arquitetônico é o protagonista central em uma intervenção, objeto para o qual estarão voltadas todas as questões e considerações; matéria de partida para as operações de projeto acontecerem; documento em que estão concretizados os valores artísticos, históricos e a perpetuação da memória que fornecerá os subsídios para as escolhas do partido para o projeto de restauro.

Para compreender o cenário brasileiro, no que diz respeito à valorização de seu patrimônio e a materialização de quais valores, quais critérios e como os desafios da intervenção e conservação dos monumentos arquitetônicos são consumados na prática; e, principalmente como a palavra "restauro" vem sendo empregada na atualidade, foram analisadas, a partir de uma amostragem reduzida, 32 estudos de caso. O estudo aprofundado dessas obras permitiu esclarecer como ocorre a intervenção no monumento a partir do edifício de partida (colonial, eclético, industrial, moderno), das premissas precedentes, do confronto com a legislação, sua história, características estéticas, o papel do arquiteto autor da intervenção.

Foram estabelecidas oito tendências de intervenção (autonomia, diferenciação, reinterpretação, repristino, apropriação, completamento, conservação e reintegração) mais recorrentes no conjunto total de obras, criando grupos com características semelhantes entre si, não totalmente rígidos e fechados, mas que de alguma forma pudessem facilitar a leitura das obras e caracterizar o panorama de intervenções no Brasil em relação ao campo disciplinar de restauro.

PERMANÊNCIA E INOVAÇÃO; PRESERVAÇÃO E MUDANÇA: VALORES DE REMEMORAÇÃO E VALORES DE CONTEMPORANEIDADE

"Permanência", "inovação", "preservação" e "mudança” são termos que estarão presentes recorrentemente nas discussões sobre a relação entre antigo e novo e no movimento de continuidade imbuído nas intervenções em edificações preexistentes. Se de um lado a "preservação" tem como objetivo garantir a integridade de algo, por outro, a "mudança" é instigada 
pelo movimento do tempo em alterar e modificar algo. Da mesma forma, a "permanência" como constância e continuidade de algo no arco temporal implica no surgimento do "novo", da novidade, da "inovação".

O denominador comum entre esses quatro termos, referências para as análises desta pesquisa, é o tempo - o tempo que divide a continuidade em passado, presente e futuro, cada qual com uma atuação dominante.

A arquitetura, como já dito anteriormente, passa pelo tempo: as edificações do passado se perpetuam no presente, carregadas ou não de valores simbólicos, testemunhos de memória, qualidades artísticas e valores históricos. No presente surgem novas arquiteturas, que serão passado no tempo futuro, mas que impõem novidades e novos valores - de contemporaneidade - no seu tempo. É um ciclo no qual permanência e inovação ora caminham em paralelo, ora se cruzam. Quando se encontram é porque estão atuando no mesmo espaço, em um edifício do passado com valores que interessam ao presente - e é neste momento que a arquitetura do passado adquire caráter de monumento.

A inserção dos monumentos na vida atual tem se tornado cada vez mais presente nas discussões do cenário da arquitetura contemporânea. A apropriação dos bens culturais desperta interesses que vão desde sua rememoração como testemunho de uma herança coletiva nos aspectos sociais implícitos isoladamente ou no contexto da vida urbana, a sustentabilidade no aproveitamento de estruturas existentes até o valor econômico e de consumo que pode gerar a readequação de uma preexistência para uma nova função.

A sociedade atual, desde a segunda metade do século passado, movida pela indústria cultural, tendo a montante as condições econômicas e sociais, tem desenvolvido uma série de empreendimentos isolados ou contextualizados em zonas da cidade para impor um novo ritmo à utilização da preexistência histórica, dando-lhe condições de permanência na vida presente.

Françoise Choay coloca esse fenômeno como fruto da relação da sociedade ocidental com a temporalidade e a construção de sua identidade. A expansão do termo de "patrimônio histórico e artístico" para "bem cultural", associada à democratização do saber e ao desenvolvimento da sociedade ligada ao turismo cultural, contribuiu em muito para a forma de consumo dos monumentos na atualidade ${ }^{7}$. 
Henri-Pierre Jeudy e Andreas Huyssen relacionam essa manifestação de apreensão do passado com uma preocupação pela perda e, consequentemente, obsessão pela ideia de rememorar. Para rememorar é preciso conservar o passado mantendo-o contínuo. A constância do monumento em que estão imbricadas as lembranças e heranças que se quer guardar, só se verifica com a manutenção de sua utilização, mas em um tempo diferente daquele em que foi concebido ${ }^{8}$.

As questões de memória e esquecimento e os valores inovativos advindos com as mudanças da sociedade contemporânea estão profundamente relacionados ao modo de lidar com nossos monumentos do passado - por serem os detentores dos valores simbólicos e porque é neles que está materializada a passagem do tempo.

Encontrar o ponto de equilíbrio entre o que preservar e o que esquecer, dando aos monumentos uma nova função temporal ao permitir que persistam em um novo contexto espaço-temporal, conservar seus valores significativos, sejam eles materiais ou imateriais, é a essência que permeia a conservação da preexistência histórica.

Ao dotar um monumento de nova função temporal, com ou sem alteração de seu uso original, a intervenção deve responder pelas expectativas do presente conservando tanto quanto possível a gramática do texto arquitetônico original em que são reconhecidos os valores históricos, artísticos e espirituais da obra. É nesse sentido que entendemos a restauração: como uma intervenção na preexistência histórica pautada no reconhecimento de seus valores, na sua preservação e transmissão para as gerações futuras.

\section{RESTAURAÇÃO: O SENTIDO DA PALAVRA}

Sendo o fazer arquitetônico o resultado da atividade humana na qual se encontra materializada a criatividade do artista e a incidência cultural de cada época em que é produzido e, também, atividade em que se operam as intervenções, cada momento histórico, a seu modo, produziu restaurações - ainda que este termo não tenha sido utilizado técnica e cientificamente -, sejam elas feitas com o máximo respeito ou com transformações

Liberdade / Ed. Unesp, 2001, p.208-211.

8. JEUDY, Henri-Pierre. Espelho das cidades. Rio de Janeiro: Casa da Palavra, 2005, p. 16. 
que levaram a destruições.

A palavra restauração foi empregada com os mais diversos sentidos ${ }^{9}$ até se tornar uma disciplina teórica e prática, no século XIX, quando os monumentos adquiriram valor de referência da nacionalidade, possuidores da memória afetiva e representantes da identidade de um povo.

No decorrer da história, ora com maior, ora com menor enfoque, o tema da preservação, conservação e restauração dos bens culturais será pauta de novas discussões. A questão do patrimônio recebeu diferentes abordagens conceituais, sendo debatida, com maior ou menor intensidade, em torno do seu caráter simbólico, ou estético, ou histórico e, até mesmo, no que diz respeito à atribuição ao patrimônio, de identidade nacional.

Hoje, no início do século XXI, o que se entende por restauro?

Segundo a definição de restauração presente no art. 9 da Carta de Restauro de Veneza, a premissa de conservar e revelar valores do monumento ou bem cultural (seja uma arquitetura, uma pintura, uma escultura) é algo compartilhado pelos pensadores do campo do restauro atual como forma de transmitir esse valor simbólico e memorial para o futuro.

A restauração comporta mudanças, modificações, podendo ser de maior ou menor vulto de acordo com o estado do monumento original e sua destinação de uso; porém, o respeito pela matéria é outro critério em pauta na ação de restauro, seja ele estético ou histórico. As transformações podem estar ligadas à consolidação estrutural, minimização das patologias de degradação, facilitação da leitura do texto original.

Stella Casiello ${ }^{10}$ salienta que a ampliação do campo disciplinar tem provocado um grande aumento na dialética inovação $\mathrm{X}$ conservação nas ações de intervenção e tornado a restauração uma ação cada vez mais complexa.

Roberto Pane e Cesare Brandi, antes mesmo do conflito mundial já acenavam para uma revisão sobre como lidar com a conservação e restauração das obras do passado. Brandi, com a criação do Istituto Centrale del Restauro

9. DE ANGELIS D'OSSAT, Guglielmo. Restauro: architettura sulle preesistenze diversamente valutate nel tempo. Palladio, Roma, terza serie, anno XXVII, fasc. 2, p. 54, 1978.

10. CASIELLO, Stella (a cura di). Restauro. Criteri, metodi, esperienze. Napoli: Electa Napoli, 1990. 
$(\mathrm{ICR})^{11}$, inaugurado em $1939^{12}$, pode atuar diretamente sobre a obra de arte, sendo o primeiro a desenvolver princípios de restauro que deram origem a uma teoria, culminando com a publicação de sua Teoria da Restauração ${ }^{13}$.

Em sua teoria, ele define restauração como "o momento metodológico do reconhecimento da obra de arte, na sua consistência física e na sua dúplice polaridade estética e histórica, com vista a sua transmissão para o futuro"14. Anos antes havia escrito no texto Il fondamento teórico del restauro ${ }^{15}$ que:

si intende generalmente per restauro qualsiasi attività svolta per prolungare la conservazione dei mezzi fisici ai quali è affidata la consistenza e la trasmissione dell'immagine artistica, e si può anche estenderne il concetto fino a comprendere la reintegrazione, quanto è più possibile approssimativa, di una mutila immagine artistica.

Brandi atribui ao ato de restauro um juízo crítico: crítico para o reconhecimento da obra de arte em si, crítico para o julgamento da dúplice polaridade estética e histórica. Toda a sua teoria será embasada nesse princípio.

Igualmente, Roberto Pane afirmará que a operação de restauro é um processo crítico e também criativo, individuando cada monumento como um caso único. Assim como Brandi, julga que o restauro do monumento é determinado pelos seus valores estéticos e históricos e que só o juízo crítico de suas qualidades, de acordo com a individualidade da obra, poderá conduzir a intervenção ao absoluto rigor.

Bonelli também terá um papel importante na conceituação da restauração. Em seu verbete Restauro Architettonico ${ }^{16}$, define arquitetura como

11. Desde 2007 o ICR passou a chamar-se Istituto Superiore per la Conservazione ed il Restauro (ISCR). Fonte: <http://www.icr.beniculturali.it/>.

12. RUSSO, Valentina. Giulio Carlo Argan. Restauro, critica, scienza. Firenze: Nardini Editore, 2009, p. 32 13. Sua teoria foi publicada inicialmente em artigos no Bolettino dell'Istituto Centrale di Restauro, a partir de 1950. A primeira publicação como livro "Teoria del Restauro" foi em 1963. No Brasil, a obra, traduzida por Beatriz Mugayar Kühl, foi publicada pela primeira vez em 2004.

14. BRANDI, Op. cit., p. 30.

15. "Entende-se geralmente por restauração qualquer atividade desempenhada para prolongar a conservação de meios físicos aos quais é confiada a consistência e a transmissão da imagem artística, e pode-se ainda estender desta o conceito até compreender a reintegração, quanto e o mais possível aproximativa, de uma imagem artística mutilada". Trad. Irene Thiago. Idem. Il fondamento teorico del restauro. Bollettino dell'Istituto Centrale di Restauro, Roma n. 1, 1950, p. 5. 16. BONELLI, Renato. Il restauro architettonico. In: BRANDI, Cesare, et. al. Voce Restauro. In: Enciclopedia Universale dell'Arte, v. XI, col. 322 e ss. Venezia-Roma, 1963. 
obra de arte, e assim como Brandi e Pane, que deve ter seu valor reconhecido. Em sua acepção, o reconhecimento do valor da obra de arte é um ato crítico em que se definem as condições de intervenção pautadas no rigor e respeito pelo monumento. Ao mesmo tempo, o restauro vem associado a um ato criativo no qual as condições preestabelecidas assumem o caráter de posturas. Para Bonelli, quanto maior a dose de fantasia - referência ao ato criativo -, maior o prejuízo ao monumento. A correta dosagem entre crítica e criatividade deve orientar as intervenções na preexistência histórica. Sendo o restauro uma operação pautada na conservação e revelação de valores do monumento, o ato crítico guiará o respeito pela preexistência, o controle das ações e as escolhas advindas da inovação, atitude esta que deve facilitar a leitura da obra: a fantasia ou a inovação, fruto da criatividade do arquiteto autor da intervenção, vem associada ao controle e responsabilidade que garante a qualidade do projeto de restauro.

O historiador da arte Paul Philippot compartilha da mesma tese de Brandi ao afirmar que o restauro é antes um problema crítico que técnico ${ }^{17}$, do mesmo modo que quando afirma que "determinare ciò che deve essere conservato e restaurato è, innanzitutto, riconoscere l'opera d'arte nella sua individualità (grifo nosso), il documento nel suo proprio significato"18. Seu entendimento do que é a intervenção de restauro também vai de encontro às afirmações de Pane em que cada monumento deve ser tratado como caso único.

O autor Giovanni Carbonara ${ }^{19}$ chama a atenção para o fato de que é necessário o estabelecimento de critérios, como rigor metodológico, criatividade, valor reconhecido pela coletividade, vontade de perpetuar o bem às gerações futuras, não contraposição de restauro e projeto para verificação do caráter da intervenção, para estabelecer fundamentos ao se tratar do discurso entre antigo e novo.

Como as premissas disponíveis na Carta de Restauro de Veneza (documento basilar para as ações de intervenção) são passíveis de interpretação, não

17. TORSELLO, Paolo (org.). Che cos"e il restauro? Nove studiosi a confronto. Venezia: Marsilio Editori, 2005. p. 61.

18. "determinar o que deve ser conservado e restaurado é antes de tudo reconhecer a obra de arte na sua individualidade (grifo nosso), o documento no seu próprio significado". Trad. Irene Thiago. Ibidem.

19. CARBONARA, Giovanni. Architettura e restauro oggi a confronto. Palladio, Roma, n. 35, , p.99-128, 2005. 
existe apenas um restauro correto, mas uma gama de escolhas que tem como intuito alcançar a intervenção mínima para a conservação do monumento. Pode haver mais de uma interpretação plausível pautada no rigor metodológico com respostas projetuais diversas, uma vez que a ação de restauro faz parte de um processo de projetação no qual, associada à preservação da preexistência, não pode deixar de aparecer a ação criativa do arquiteto.

O tema é controverso e tem divido as opiniões da cultura da restauração. Um restauro nada mais é do que um ato criativo que propõe uma arquitetura nova (seja ela uma modificação mínima ou de maior vulto) sobre uma arquitetura já existente: a intervenção revela-se como a presença $\mathrm{da}$ atualidade frente àquele bem.

A Carta de Veneza, ao dizer que a restauração "tem como objetivo conservar e revelar os valores estéticos e históricos do monumento e fundamenta-se no respeito ao material original e aos documentos autênticos" não deixa claro o pertencimento da ação de restauro ao campo da projetação. A esta falta de clareza se acrescenta que:

a conservação e a restauração dos monumentos constituem uma disciplina que reclama a colaboração de todas as ciências e técnicas que possam contribuir para o estudo e a salvaguarda do patrimônio ${ }^{20}$.

De fato, a restauração é um campo em que devem atuar diversas disciplinas para que sejam criadas condições de aprofundamento: do conhecimento matérico do monumento (com a ajuda da engenharia e das ciências químicas e físicas); da crítica sobre seus aspectos estéticos e históricos (conhecimento da história da arquitetura); das razões de tutela e conservação (em referência à crítica, história e arqueologia). Todas essas disciplinas servirão de suporte para a materialização de um projeto de restauro no qual a prática será legitimada pela arquitetura.

Todo projeto de restauro é feito pela complementação do antigo com o novo, qualquer que seja a dimensão da intervenção. Toda restauração gera uma modificação no monumento e essa mudança deve ser objeto de projeto, do ato criativo previamente estabelecido. Tanto o projeto de restauro como 
o projeto do novo pressupõe uma metodologia em que o ato de projetar é subsidiado por critérios, legislação, programa, composição, história, função. Porém, na restauração, a criatividade ligada ao ato de projetar também deve lidar com a operação conservativa, de revelação de valores de integração de lacunas/remoção de acréscimos, pautados no respeito e juízo crítico em relação ao monumento. É isso o que diferencia um projeto de restauro arquitetônico de um projeto arquitetônico do novo - o que Paul Philippot chama de reconhecimento do outro ${ }^{21}$.

$O$ restauro parte de uma entidade preexistente, na qual ocorrerão as ações de transformação guiadas pela reversibilidade, mínima intervenção, distinguibilidade e compatibilidade de materiais, após a revisão crítica do texto original. Quando Philippot coloca o reconhecimento do outro, é justamente a interpretação da matéria, em seus aspectos estético, histórico, econômico e espiritual que deverão ser interpretados e avaliados para que das ações de intervenção resultem um bom projeto de restauro.

De acordo com Giovanni Carbonara, a conservação e a restauração implicarão em mudanças na estrutura e no aspecto do monumento. As decisões de modificação envolvem a formação de um profissional conhecedor das normas de segurança, dos sistemas de infraestrutura, das prescritivas de acessibilidade e, acima de tudo, que tenha crítica e autocrítica para solucionar essas questões do ponto de vista estético.

in realtà complessa come l'architettura, la risposta a queste esigenze passa attraverso un momento consapevole di progettazione, per quanto intesa a fini conservativi e restaurativi, non astrattamente manipolativi o reconfigurativi", o arquiteto deve ser "paziente nell'ascoltare la preesistenza e sensibile, soprattuto consapevole d'intervenire su preziose testimonianze materiali di civiltà e d'arte ${ }^{22}$.

21. CARBONARA, Op. cit.

22. "em uma realidade complexa como a arquitetura, a resposta a esta exigência passa por um momento consciente de projeto, uma vez que compreendida com fins conservativos e restaurativos, não abstratamente manipulativos ou reconfigurativos, o arquiteto deve ser paciente no escutar a preexistência e sensível, sobretudo consciente de estar intervindo sobre preciosos testemunhos materiais de civilização e de arte". Trad. Irene Thiago. CARBONARA, Giovanni. Preesistenze e progetto architettonico. In: MALFONA, Lina. Per una definizione del progetto. Roma: Edizioni Kappa, 2010. p.17. 
Há diferença entre um projeto de restauro e a projetação do novo. $\mathrm{O}$ primeiro trabalha com uma matéria preexistente, com carga histórica e artística, que está submetida a uma legislação específica e que possui um significado memorial e simbólico para uma determinada coletividade. No projeto do novo, uma matéria nova será construída, e a partir da sua consolidação é que será possível criar vínculos com a coletividade e tornar-se testemunho material e espiritual de seu tempo. No entanto, ambos são projetos de arquitetura, devem seguir: legislações urbanísticas e de edificação, conhecimento e respeito pelo entorno, agenciamento de programas definidos pelo cliente, incorporação de técnicas e materiais construtivos compatíveis com os projetos.

\section{O CENÁRIO ATUAL}

As modalidades de aproximação entre arquiteturas de diferentes épocas têm utilizado as mais variadas construções linguísticas, como relatado no item anterior. E foi a partir dessa concordância de palavras que Lucia

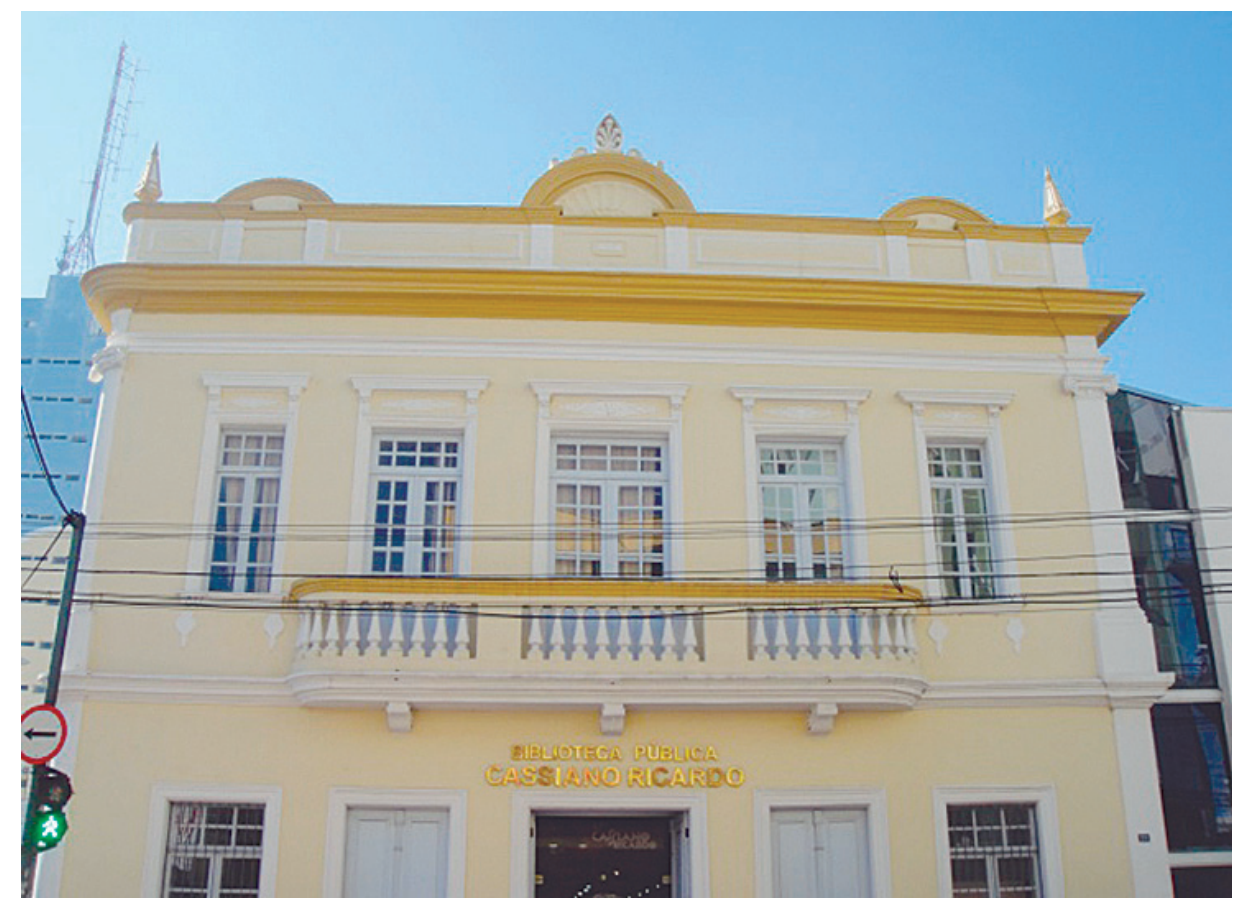


Serafini analisou "Il destino della preesistenza nel restauro contemporâneo"23 : utilizando-se dos vocábulos staccate (destacado), sopra (sobre), acanto (ao lado), mezzo (no interior), tra (entre), a autora coloca que o restauro atual está sujeito a experimentação de operações projetuais de sobreposição, justaposição e intrusão.

Claudio Varagnoli,alguns anos antes, através do que chama de modalidades ${ }^{24}$, também iniciou um estudo na tentativa de separar as intervenções

23. SERAFINI, Lucia. Sopra, accanto, con l'antico. Il destino della preesistenza nel restauro contemporaneo. In: FERLENGA, Allberto; VASSALLO, Eugenio; SCHELLINO, Francesca (org.). Antico e Nuovo. Architetture e Architettura. Atti del Convegno "Antico e Nuovo. Architetture e Architettura", Venezia 31 de marzo - 3 aprile 2004, 2 vol. Padova: II Poligrafo, 2007.

24. Claudio Varagnoli adota seis modalidades tipológicas: 1. "Guscio/contenitore" (casca/contentor); "Decodificazione" (decodificação); "Differenziazione di linguaggio" (diferenciação de linguagem); "Riconstruzione" (reconstrução); "Restituzione" (restituição); "Dislocazione” (deformação).

FIGURA 2

Interior da Biblioteca Cassiano Ricardo. Foto da autora.

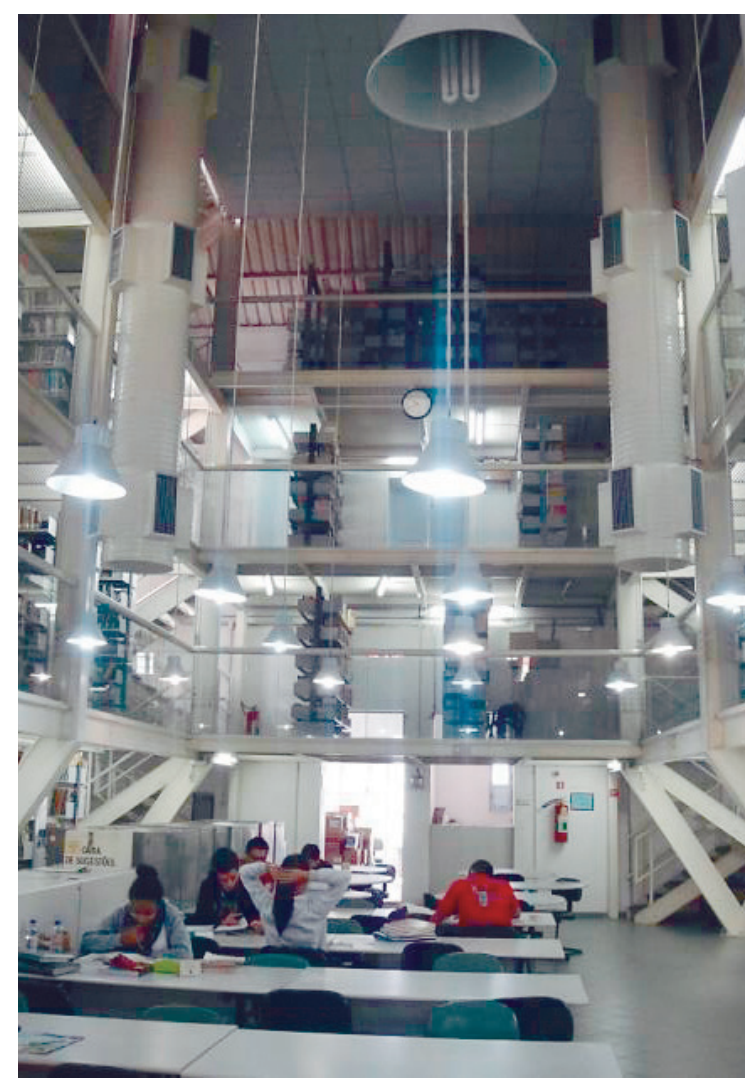


em monumentos a partir de características em comum.

Ele conclui que o diálogo entre arquitetura contemporânea e monumento histórico não pode se justificar só pelo produto final, mas deve ser resultado do rigor metodológico, valor reconhecido pela coletividade, preservação dos extratos da história, forma e composição a partir de um juízo crítico da obra do passado ${ }^{25}$.

No recente livro Architettura d'oggi e restauro: un confronto anticonuovo ${ }^{26}$, Giovanni Carbonara procura definir justamente este papel da arquitetura contemporânea junto aos monumentos do passado como forma de avaliar o diálogo entre antigo e novo em intervenções na preexistência edilícia. Ao introduzir suas categorias e exemplos de intervenção, Giovanni Carbonara faz referência aos estudos de Claudio Varagnoli que, conforme citado, em 2002 foi o primeiro a traçar uma tentativa de definição de categorias de análise de interpretação das intervenções na preexistência ${ }^{27}$.

Para discutir esse fenômeno no Brasil, o estudo definiu como recorte geográfico e temporal, a produção arquitetônica brasileira em programas de intervenção em edifícios de valor histórico e artístico no período compreendido entre os anos 1980 a 2000. Pois foi na década de 1980 que o cenário nacional assistiu a um crescente número de projetos de intervenção de caráter monumental realizados fora dos órgãos responsáveis pela tutela do patrimônio nacional, fruto, principalmente, da gradativa descentralização do órgão federal.

As principais premissas integrantes da Carta de Restauro de Veneza, fruto das disposições resultantes do debate no pós-guerra, principalmente

VARAGNOLI, Claudio. Edifici da Edifici: la ricezione del passato nell'architettura italiana, 1990200o. L'industria delle costruzioni, Roma, anno XXXVI, n. 368, p.5, nov.-dez. 2002.

25. VARAGNOLI, Claudio. Op. Cit., p.5.

26. CARBONARA, Giovanni. Architettura d'oggi e restauro: un confronto antico-nuovo. Torino: UTET Scienze Tecniche, 2011.

27. As categorias elencadas por Carbonara são: “Autonomia/Dissonanza"'(autonomia/dissonância), é dividida em três subcategorias (Contrasto/Opposizione; Distacco/Indifferenza; Distinzione/ Non Assonanza); "Assimilazione/Consonanza” (assimilação/consonância), também dividida em três subcategorias (Mimesi/Ripristino; Analogia/Tradizione; Restituzione tipologica); "Rapporto dialettico/Reintegrazione dell'immagine" (relação dialética/reintegração da imagem) onde encontramos as subcategorias Dialettica critico-creativa/Reinterpretazione; Filologia Progettuale/ Coestensione e Reintegrazione dell'immagine/Accompagnamento conservativo. CARBONARA, Giovanni. Op. cit., p.111-124. 
aquele proposto pelos expoentes do Restauro Crítico, nortearam a identificação das posturas recorrentes nas obras do mapeamento. Cada intervenção foi avaliada nos seguintes aspectos: segundo sua destinação útil na atualidade, um dos principais motivos do projeto de intervenção; quanto à alteração da gramática original do monumento em relação às suas características estéticas e históricas; quanto ao julgamento histórico-crítico em remover acréscimos e reintegrar lacunas; sobre a adoção de materiais e técnicas adequados; e sobre a volumetria final da obra no que diz respeito ao seu aspecto formal.

Essa avaliação resultou em algumas modalidades de diálogo que deram origem a oito tendências de intervenção mais recorrentes no conjunto total de obras analisadas. No que diz respeito à valorização de seu patrimônio e à materialização de quais valores, quais critérios e como os desafios da intervenção em monumentos preexistentes são consumados na prática, e,

FIGURA 3

Casa de Cultura Mário Quintana: fachada posterior onde foi incorporada a cobertura em estrutura metálica e vidro. Foto da autora.

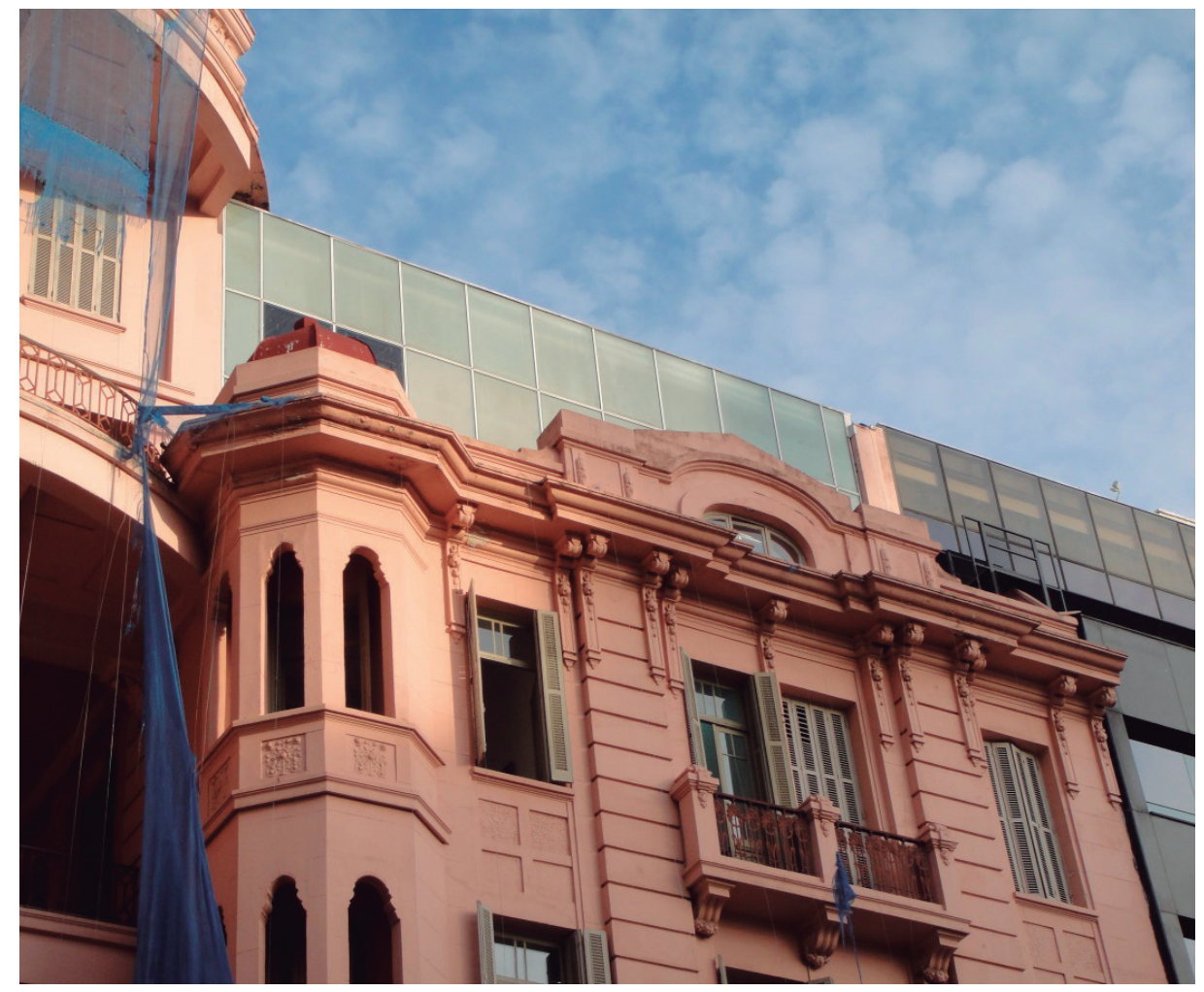


FIGURA 4

Hall principal do Centro Cultural Banco do Brasil antes da intervenção. Fonte: CARAM, André Luis Balsante. Pujol: concreto e arte.

São Paulo: Centro

Cultural Banco do Brasil/Instituto Takano, 2001

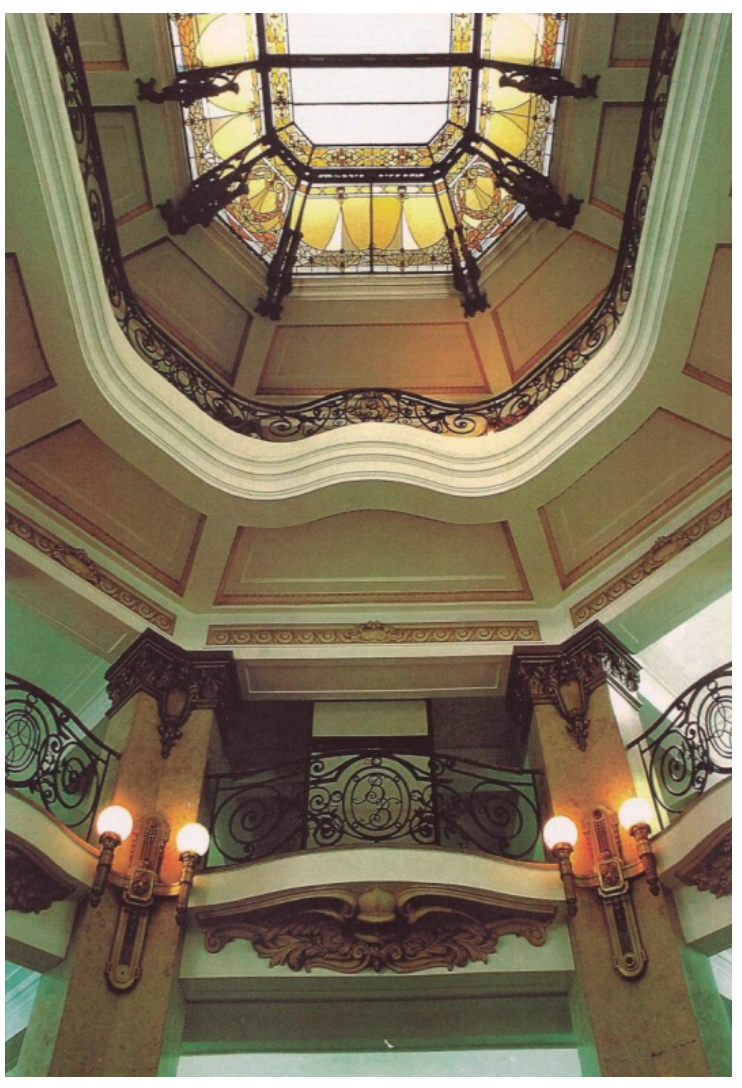

FIGURA 5

CORBIOLI, Nanci.

Agência bancária restaurada é devolvida à cidade como espaço cultural. Projeto Design, São

Paulo, n. 256, p. 61-65, jun. 2001

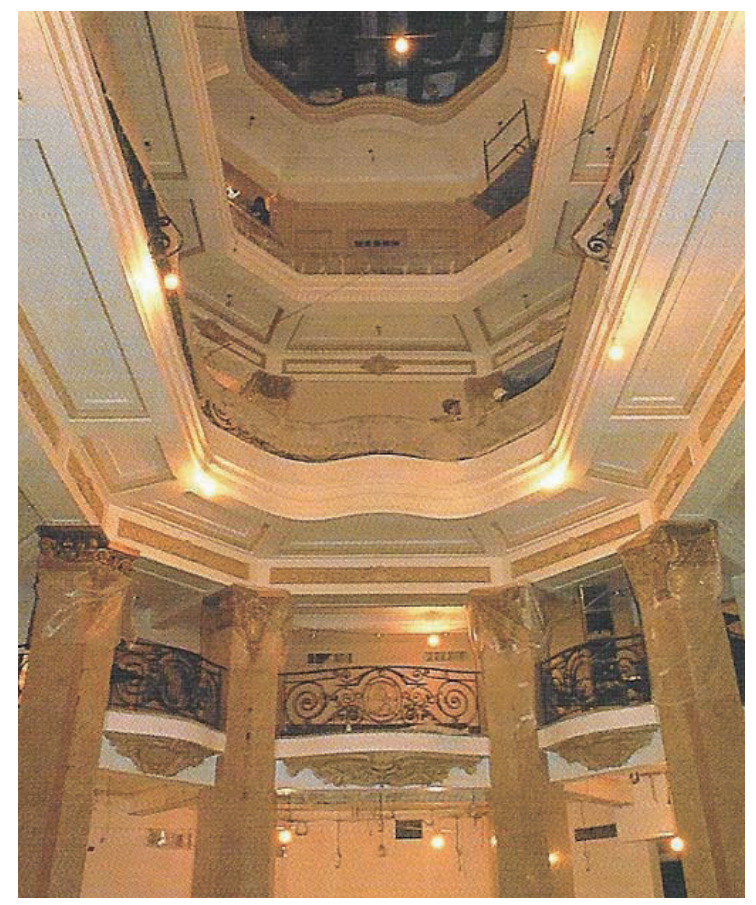


principalmente, como a palavra "restauro" vem sendo empregada na atualidade, foram observadas, a partir de uma amostragem ${ }^{28}$, quais tendências permeiam o debate no Brasil: autonomia, diferenciação, reinterpretação, repristino, apropriação, completamento, conservação e reintegração.

\section{AS TENDÊNCIAS DE INTERVENÇÃO NO BRASIL}

A forma como os diálogos antigo e novo são absorvidos no processo de projeto, como o monumento é velado ou revelado e como o tempo passado estabelece conexão com o tempo presente contextualizará a obra dentro de uma ou outra tendência e a postura projetual oriunda dessas escolhas aproximará ou afastará a intervenção do campo do restauro.

Em "autonomia”, a intervenção considera como elemento a ser preservado apenas o invólucro do monumento, que é tratado como um contentor da obra. Em geral, há mudança de uso, pois essa "autonomia" entre antigo (monumento) e novo só se verifica com uma destinação diversa da função original, propondo a necessidade do destaque entre ambas as estruturas.

O contentor (a "casca") é conservado com os elementos formais que o caracterizam como arquitetura de uma determinada época, mas seu conteúdo interno é inteiramente novo e independente: em alguns casos ainda encontramos a manutenção de componentes internos, como uma parede remanescente, um ornamento arquitetônico de valor, um elemento histórico, mas eles tornam-se mais um dado estranho à edificação do que parte da unidade da obra. A intervenção na Biblioteca Cassiano Ricardo (um antigo teatro de 1909) em São José dos Campos, realizada pelos arquitetos Guilherme Lemke Motta e Antonio Luiz Dias de Andrade entre 1995/1997 29 , apresenta características bem representativas dessa tendência. Externamente, a Biblioteca Cassiano Ricardo preservou todo o perímetro do monumento, porém, no interior, a edificação foi esvaziada de todos os seus componentes. $\mathrm{O}$ antigo teatro perdeu sua configuração interna com a remoção dos elementos estruturadores (lajes e divisórias) para dar lugar a uma estrutura metálica perimetral com quatro pavimentos, ajustados ao

28. Cf. NAHAS, Patricia Viceconti Nahas. Antigo e novo nas intervenções em preexistências históricas: a experiência brasileira (1980-2010). 2015. Tese (Doutorado em Arquitetura e Urbanismo) - Faculdade de Arquitetura e Urbanismo da Universidade de São Paulo, São Paulo, 2015. 29. As datas apresentadas para cada intervenção referem-se ao ano de realização do projeto. 
gabarito das aberturas existentes e com um grande hall central.

$\mathrm{Na}$ tendência "diferenciação", as ações adotadas na intervenção diferenciam-se do monumento através de elementos compositivos, materiais e técnicas construtivas incorporados por adição do novo e subtração do antigo. O novo é claramente distinguível do antigo em relação à forma, material, cor, estrutura. A maioria dos casos dessa tendência de diferenciação, quando não envolve mudança de uso, tem por finalidade a atualização da edificação frente às novas demandas da sociedade contemporânea.
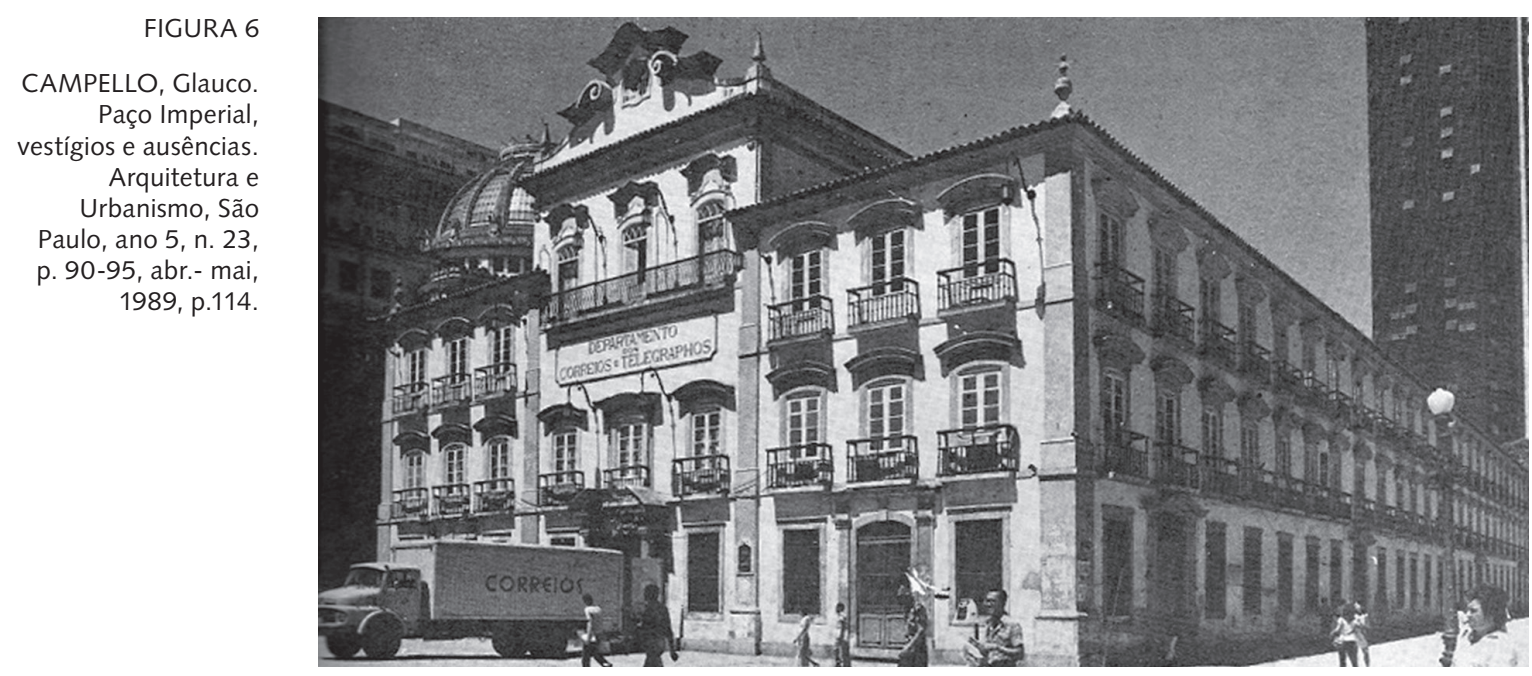

FIGURA 7

Centro Cultural Paço Imperial após a intervenção. Foto da autora.

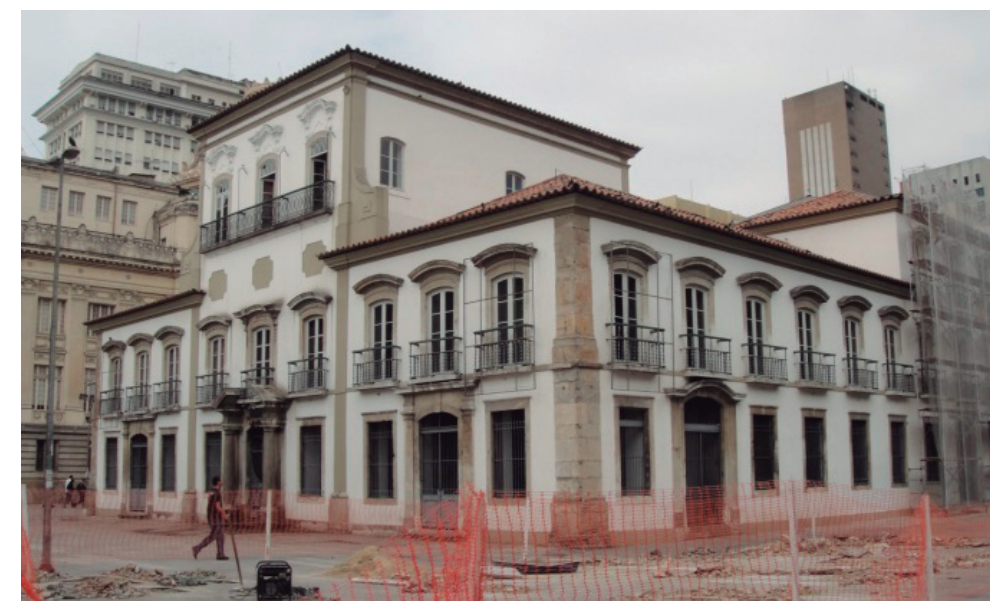


Verificamos, com este estudo, que é neste grupo que está o maior número de intervenções analisadas, o que torna essa tendência majoritária na experiência brasileira do diálogo entre antigo e novo. Em geral, as remoções e acréscimos em um monumento podem ser vistos por duas perspectivas: pela ação de tempo ou pelas interferências causadas pela nova intervenção.

As marcas do tempo adquiridas pelo monumento motivam as adições (reintegração de lacunas e complementações) e subtrações (remoção de acréscimos e retirada de elementos para substituição por composições novas), normalmente frutos da combinação destinação de uso/período construtivo do monumento/estado de conservação, e associadas ao ato criativo do autor da intervenção. As marcas do tempo estarão associadas às marcas deixadas pelo arquiteto que, neste tipo de intervenção, será a postura preponderante, e é isso o que caracteriza a tendência da diferenciação.

Por exemplo, na Casa de Cultura Mário Quintana em Porto Alegre, cujo projeto de intervenção de 1987/1988 é dos arquitetos Flávio Kiefer

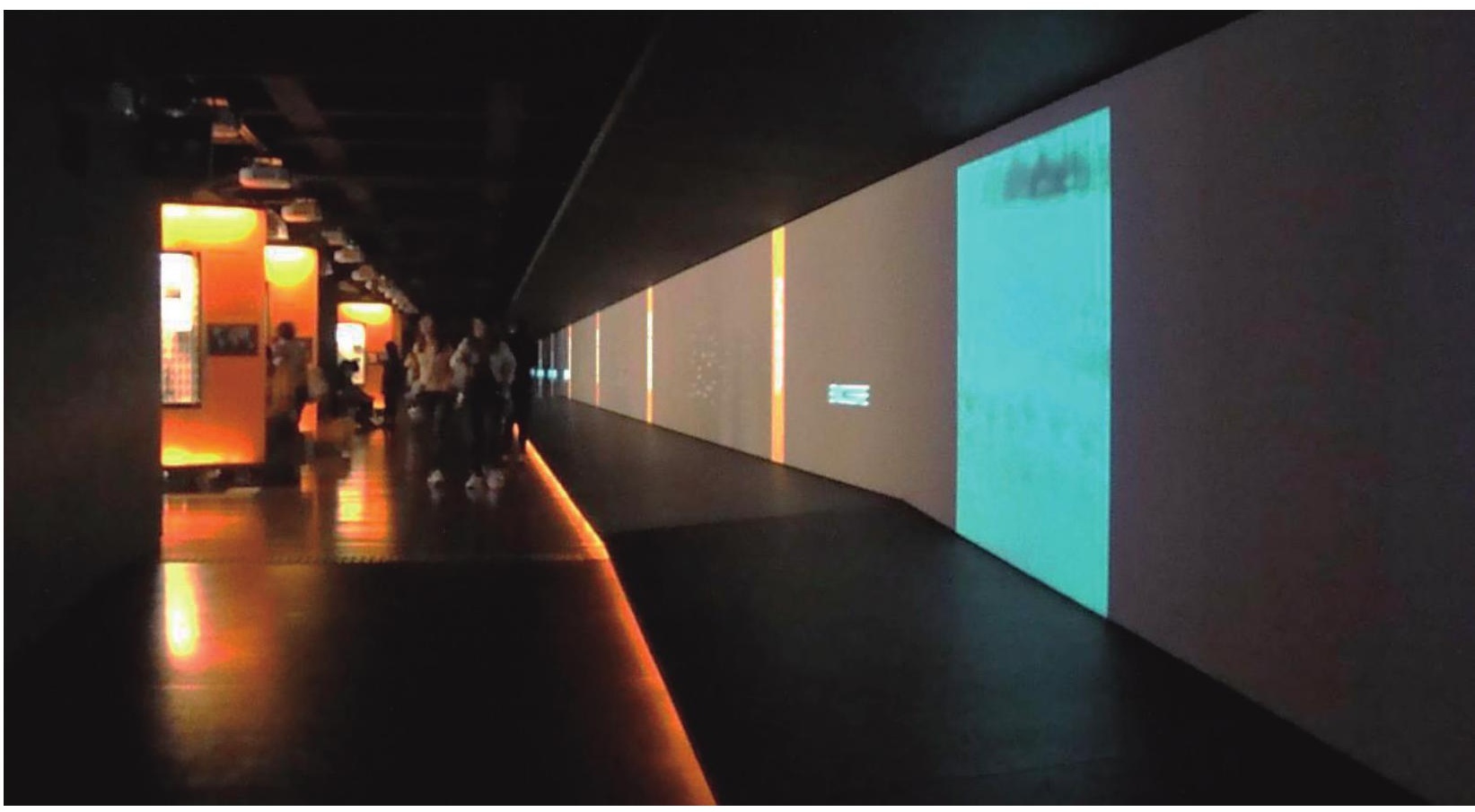


e Joel Gorski, todas as ações são prescritas pelo novo uso ao qual foi destinada a edificação, no processo de mudança de hotel para centro cultural, programa bastante distante do ponto de vista funcional e de agenciamento do partido arquitetônico.

No entanto, como para transformar em espaço cultural o antigo hotel, construído entre 1910 e 1920, é necessária a inclusão de elementos transformadores do espaço que marquem a intervenção contemporânea e deem condições ao novo uso, se recorre à adição de novos elementos verticais no interior de um edifício tão compartimentado e de implantação tão estreita, que levam a uma série de demolições e recortes para a criação de circulação vertical e horizontal.

Em "Reinterpretação", a intervenção promove uma releitura do monumento existente, ou de parte dele, por meio da interpretação de seus valores formais e funcionais remanescentes que norteiam o projeto, readequando a edificação a sua nova destinação de uso. Novos elementos são inseridos

FIGURA 9 da autora.

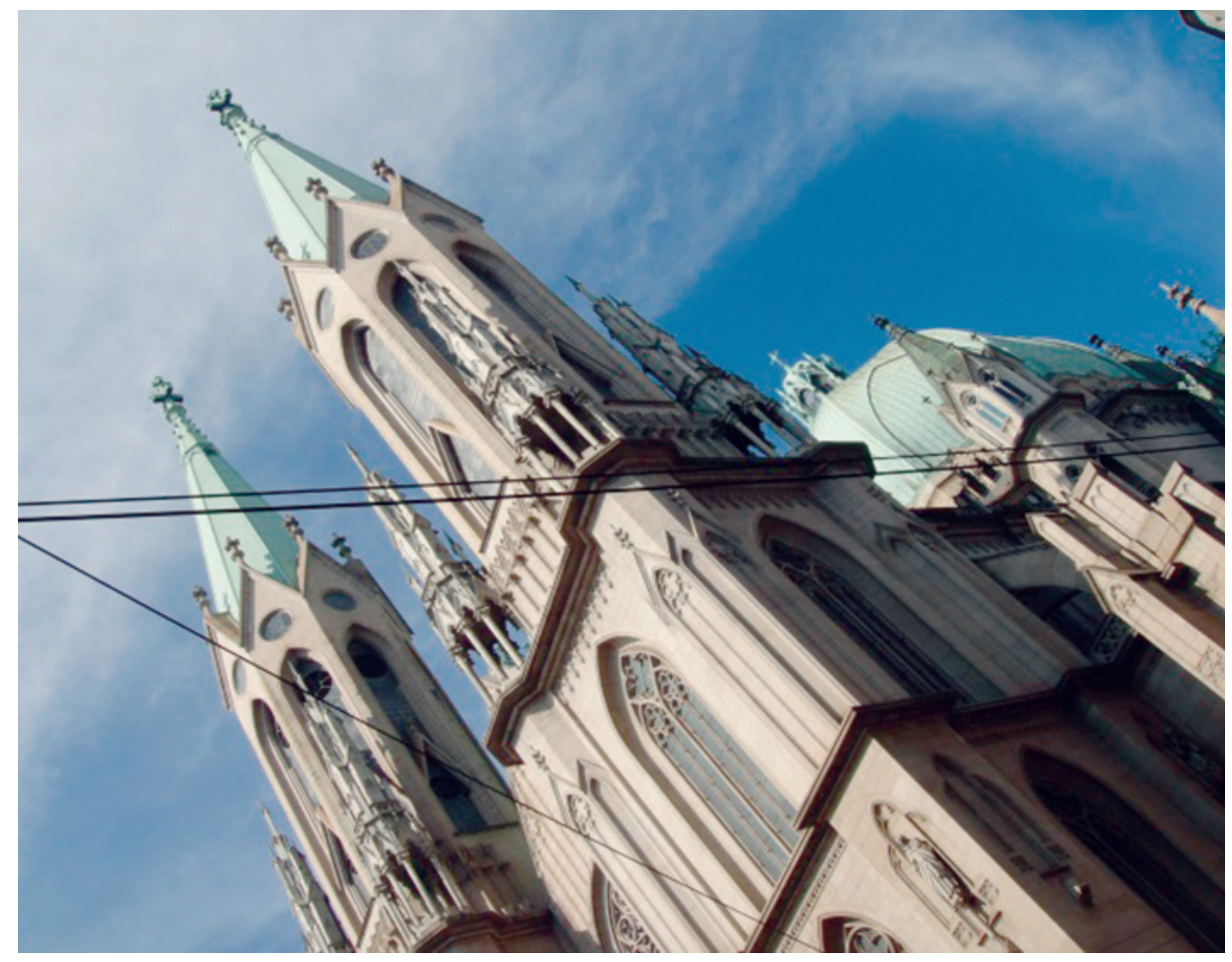


como continuidade do texto original, a partir dos dados que o monumento fornece ao autor do projeto, tendo como guias as características estéticas e testemunhos históricos do antigo edifício.

O projeto do arquiteto Luis Benedito da Silva Telles, realizado em 1999 para o Centro Cultural Banco do Brasil, em São Paulo (antiga agência do Banco do Brasil, construída em 1901 e inaugurada em 1929), reinterpreta o espaço, mas, em vez de reconfigurar totalmente com uma única ação um ambiente em suas três dimensões - a mudança do nível da claraboia -, estabelece uma nova leitura da edificação. Com o deslocamento da claraboia para alguns pavimentos acima, o espaço se amplia, enfatizando sua dimensão monumental. Essa ação não deixa de respeitar os princípios basilares do restauro contemporâneo: reversibilidade e mínima intervenção. A distinguibilidade desta engenhosa operação é algo que talvez não fique tão claro, uma vez que o arquiteto trabalhou com a própria matéria existente e não com um elemento contemporâneo, apenas alterando sua posição no espaço.

Na tendência "Repristino", temos os projetos que se pautam na postura de recuperar ou reconstruir o monumento adotando um período ou estilo que a obra já não possui mais. A desconsideração pela historicidade e arte adquiridos pela preexistência ao longo de sua vida útil é o mote desta tendência, que parte da intervenção justificada pelo desejo de refazer uma parte da construção, reproduzindo um estilo ou parte de um determinado período histórico considerado importante e, assim, recriando algo que não existe, em prejuízo de algo que já é parte do monumento.

Esta intervenção produz uma falsificação que leva o observador ao engano. Não existe parâmetro para avaliação dos princípios de restauro, pois a memória original do monumento é perdida em benefício da construção de um falso histórico.

A demolição de grande parte do terceiro pavimento para a reconstituição da volumetria e do caráter barroco que se pretendia dar ao prédio na intervenção no Paço Imperial do Rio de Janeiro (que começou a ser construído em 1743, passando por várias alterações e complementações em seu projeto original durante os séculos seguintes) representa uma perda estética e histórica para o monumento e sua preservação.

Com a autoria de Glauco Campello, José de Souza Reis, Cyro Correa Lyra e Gilberto Ferrez, a intervenção proposta em 1983 dá ao prédio uma feição que 
ele já não possuía mais, mas que reforçaria seu caráter e sua representatividade como memória do período eleito como mais significativo para o patrimônio brasileiro, leva a decisões de projeto que acabaram dando ao prédio do Paço Imperial uma configuração final nova, não representativa de nenhuma das etapas pelas quais passou a edificação. Não o vemos como um prédio antigo restaurado, mas como a concretização de um "falso histórico". Reconhecemos alguns elementos como originais do edifício preexistente, porém, sua composição arquitetônica geral como referencial de um período foi perdida.

Como "Apropriação" encontram-se as intervenções nas quais o novo é o personagem principal da ação sobre o monumento, tornando-se o antigo apenas suporte para a sua existência. Ou seja, a existência e protagonismo do primeiro é resultado de como o monumento é apropriado: como suporte para o novo, tendo o novo o domínio sobre o antigo, a posse sobre o bem histórico. A intervenção é caracterizada pela inexistência de respeito ao monumento, pois o autor da intervenção se apropria da preexistência para criar as condições adequadas para o seu projeto contemporâneo.

Não existe integração das lacunas nem remoção de acréscimos, mas,

FIGURA 10

Estudo do esquema construtivo da Estação Banana. Fonte: GONCCALVES Cristiane. KRUCHIN Portofolio Brasil: arquitetura e arte. São Paulo: JJ Carol Editora, 2006

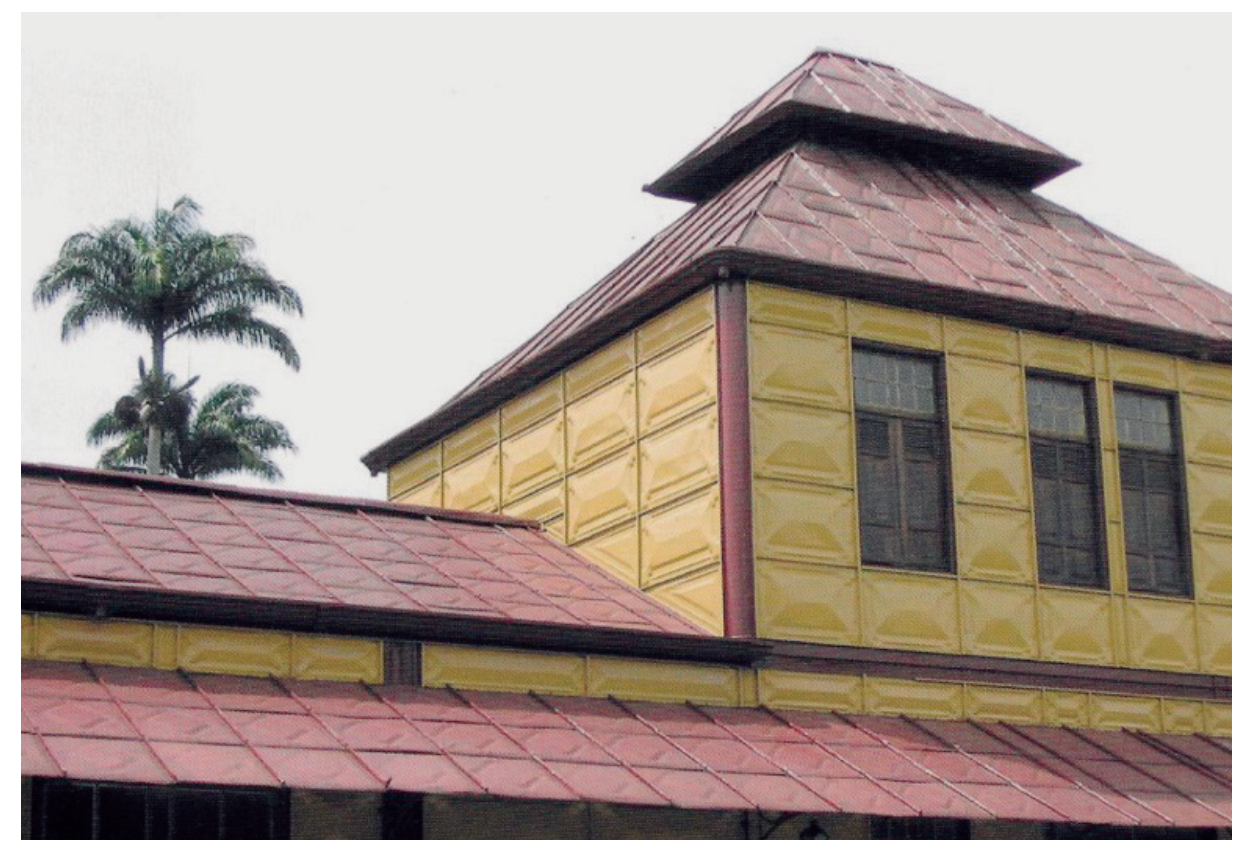


FIGURA 11

Vista exterior do Mercado Modelo após a intervenção.

Foto da autora.

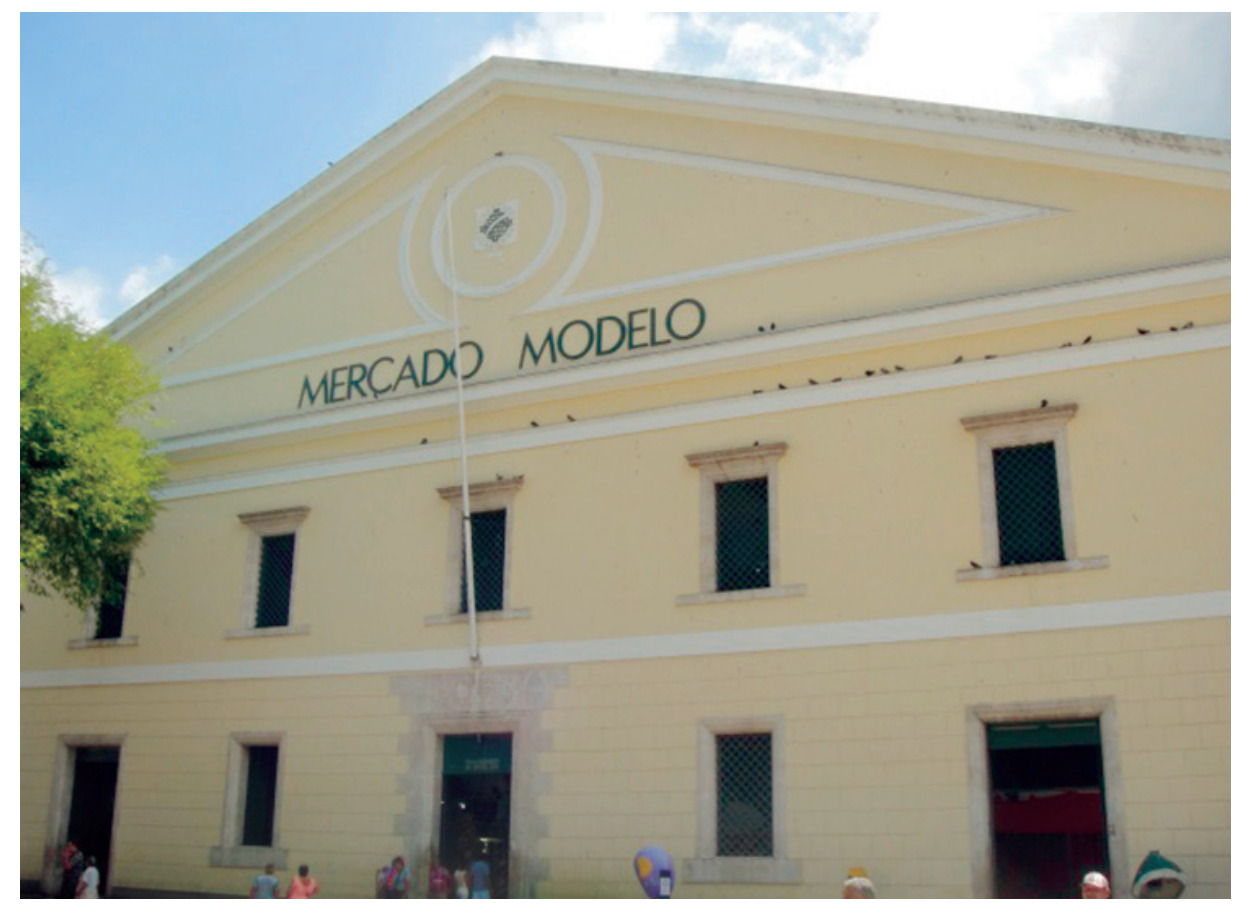

FIGURA 12

AZEVEDO, Paulo

Ormindo David

de. Alfândega e o

mercado: memória

e restauração.

Salvador: Secretaria

Planejamento,

Ciência e Tecnologia

1985. p. 73

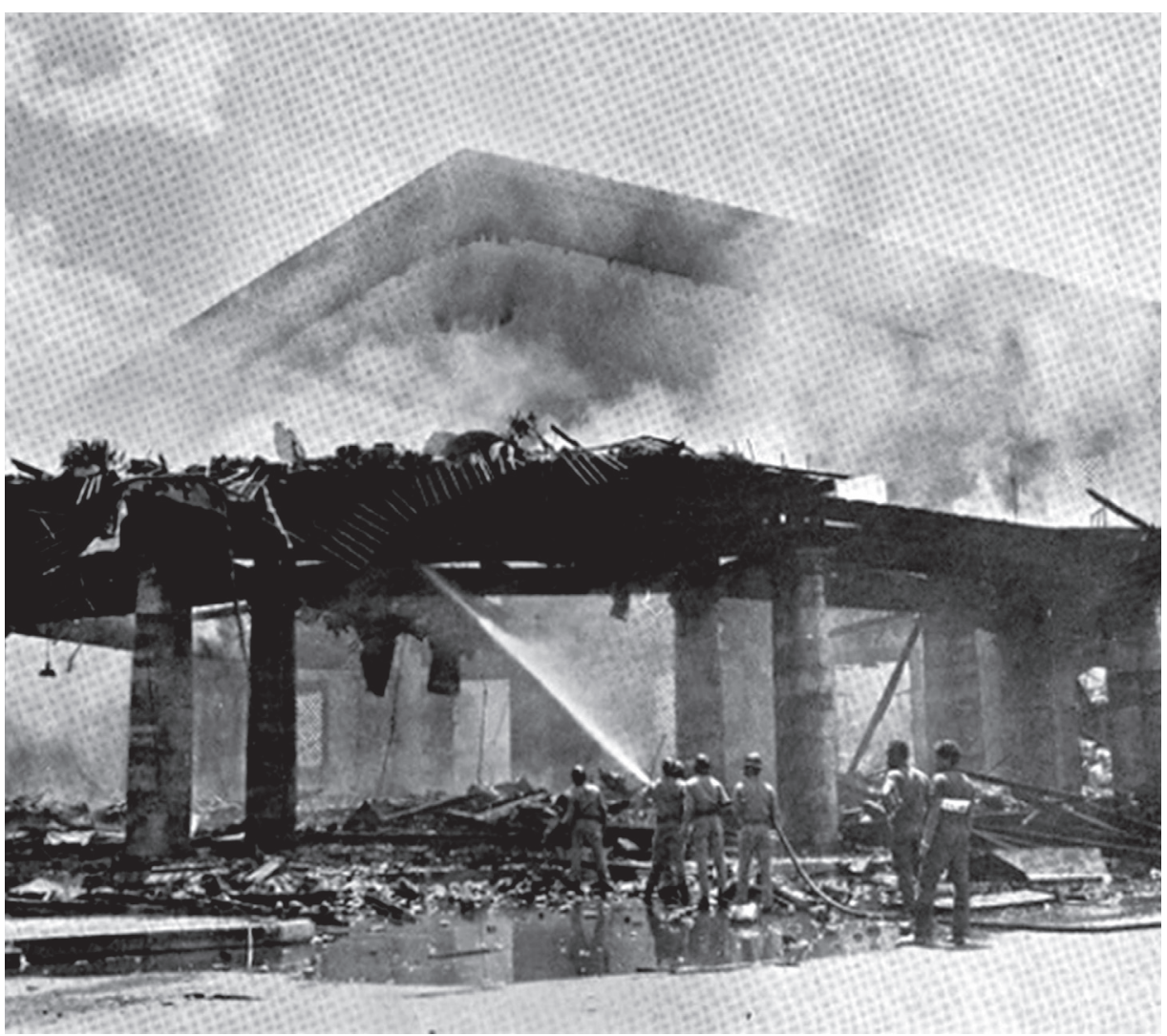


sim, adições condicionadas pelo novo, sem avaliação crítica do dado histórico e possíveis ações valorativas para sua preservação.

Em intervenção na Estação da Luz, em São Paulo, para a incorporação do Museu da Língua Portuguesa, realizada pelos arquitetos Paulo e Pedro Mendes da Rocha em 2000, encontra-se terreno fértil para a discussão dos limites da intervenção em preexistências históricas e podemos colocar em discussão até que ponto a opção por uma determinada solução de projeto pode ou deve interferir na preservação das edificações, e como a escolha feita transita no campo disciplinar da restauração. Ou seja, a adoção por uma determinada postura projetual insere ou exclui a obra do campo de restauro?

A edificação, de 1875 e reconstruída entre 1947 e 1951, necessitava de manutenção e conservação. A solução encontrada foi dotar o edifício de um novo uso que pudesse lhe dar um novo dinamismo. Esse dinamismo foi alcançado, pois o museu é um espaço de grande sucesso de público, fazendo parte do roteiro cultural da cidade. No entanto, a conquistada vitalidade acentuou a descaracterização da essência da edificação: a de uso como espaço ferroviário. Como espaço museográfico, o projeto parece ser acertado, porém, as resoluções de museografia sacrificam importantes elementos da arquitetura, arquitetura essa considerada um dos mais importantes edifícios ferroviários do Brasil e um significativo exemplar do patrimônio industrial.

Quando se percorre as galerias expositivas perde-se a referência do edifício em si devido à contraposição da virtualidade entre o museu e a realidade do prédio. Soma-se a isso a falta de entrosamento entre o espaço interno e externo, que já não existia em função do novo sistema de ingresso às plataformas da gare.

Na tendência "Completamento", a intervenção tem como objetivo dar continuidade ao edifício que não foi terminado no momento de sua criação, seguindo suas características estilísticas originais. Neste caso, há dois problemas: o completamento a partir do conhecimento do projeto original, e caso não exista esse projeto.

O monumento vem acrescido de uma camada de história de um tempo perdido, a partir de um conceito desatualizado que retoma um projeto concebido no pretérito, materializando no presente ideias passadas.

Do ponto de vista estético, a intervenção produz um "falso" histórico - algo que foi pensado, mas não realizado no projeto inicial do monumento, sendo executado em momento diverso, quando a edificação 
já adquiriu valores e testemunhos por sua imagem construída. As partes completadas, o novo objeto, podem levar o observador ao engano em relação ao momento de execução do projeto de completamento e o da execução do original. Assim, estabelece-se uma problemática de autoria do projeto, pois o monumento é fruto, aparentemente, de um único projeto realizado em tempos diferentes e por arquitetos diferentes.

O completamento da Catedral da Sé, na cidade de São Paulo, (que começou a ser construída em 1912 e inaugurada somente em 1954) foi realizado por solicitação do cliente, a Cúria Metropolitana, em um projeto que tinha por finalidade o "restauro conservativo", no qual se recuperava elementos deteriorados e com problemas estruturais. A complementação dos torreões e agulhas, previstos no projeto original mas não construídos, acabou sendo incorporada às ações de conservação, alterando o caráter da intervenção.

$\mathrm{O}$ arquiteto Paulo Bastos havia apresentado uma proposta de construir os torreões e as agulhas na mesma posição prevista no projeto original, mas com técnicas e materiais modernos, utilizando uma delgada estrutura metálica e fechamentos em vidro. Dessa forma, ele criaria a volumetria almejada, mas com um olhar contemporâneo, promoveria a releitura e a reinterpretação do projeto inacabado. Todavia, essa proposta não foi aceita pelo cliente, que queria "terminar" a construção 50 anos depois. O projeto de intervenção é de 2000.

Na tendência "Conservação", ação de restauro promovida pelo arquiteto Samuel Kruchin e equipe em 1984, é pautada na conservação do monumento, em geral mantendo seu uso original, com eventuais ajustes e adequações funcionais (segurança, conforto, acessibilidade) para atualização da edificação às novas demandas da sociedade moderna.

Nela, as etapas de projeto são acompanhadas pela avaliação crítica dos valores estéticos e históricos como garantia à preservação do monumento em seu texto arquitetônico original. A remoção de acréscimos e a reintegração de lacunas são propostas pautadas na conservação do edifício: o que não tem valor, ou prejudica a leitura da preexistência, é retirado, e só são acrescidos elementos necessários à consolidação estrutural, à atualização do bem e à perpetuação de sua vida útil, material e funcional.

Após um breve período sendo utilizado como sede dos Correios, o edifício da Estação Bananal, construído entre 1885 e 1889 na cidade de Bananal, estado de São Paulo, com um trabalho de conservação minucioso, 
foi destinado a tornar-se uma rodoviária: um uso compatível com suas instalações, mas com uma série de problemas de conservação que precisariam ser resolvidos.

A desmontagem da estrutura, facilitada por seu caráter pré-fabricado, foi decisiva para a avaliação do estado de conservação de cada um de seus componentes e para o tratamento pertinente a cada um deles - ações que visavam salvaguardar o máximo possível o monumento em sua essência.

Em "Reintegração", a intervenção geralmente ocorre em monumentos em ruína, semirruína ou fruto de uma grande descaracterização em função da má conservação ou falta de controle dos órgãos de preservação. A ação de intervenção tem o objetivo de reintegrar o edifício preexistente por meio de uma postura de saneamento, isto é, da remoção de acréscimos que descaracterizam o conjunto e com a recuperação de elementos indispensáveis à composição do monumento, isso tudo com certa dose de criatividade.

O teor artístico e histórico da obra é analisado e passa por processo de julgamento crítico sobre quais valores estão presentes na obra, quais são significativos e devem ser preservados, quais são representativos e devem ser recuperados, tudo isso visando, como resultado final, a reintegração da imagem do monumento original. A base da intervenção é a conservação do material autêntico original, através da avaliação da história do monumento, respeitando os preceitos basilares do restauro.

Em menos de um ano, e em condições financeiras precárias, o arquiteto Paulo Ormindo de Azevedo e seus colaboradores conseguiram devolver a Salvador o Mercado Modelo (construído entre 1849 e 1863; incendiado e restaurado em 1984) com suas características originais, antes comprometidas pelo incêndio sofrido: mais que um mercado popular, um mercado de artigos típicos da cultura baiana, frequentado por moradores e turistas.

Do completo estado de ruína - pois apenas suas alvenarias de cantaria estavam de pé -, a edificação foi restaurada e consolidada segundo os princípios basilares do restauro contemporâneo: o objetivo principal da ação fundamentou-se em respeitar a matéria original e, no que diz respeito às inserções, procurou, através do consolidamento da estrutura e do uso de técnicas e materiais 
contemporâneos, refazer a releitura do monumento existente antes dos danos sofridos.

\section{CONCLUSÃO}

Ainda é muito incipiente no Brasil a compreensão dos princípios basilares do restauro por parte dos arquitetos "não restauradores": mínima intervenção, distinguibilidade, reversibilidade, autenticidade e compatibilidade dos materiais. São essas as premissas a serem perseguidas pelos arquitetos autores da intervenção, em conjunção com sua interpretação das prescritivas e critérios do campo disciplinar do restauro.

A partir das ferramentas dadas ao arquiteto e da interpretação que ele faz (ou deveria fazer) das diretrizes designadas pelo campo disciplinar do restauro, a intervenção é guiada de forma que o novo seja mais um componente do antigo, mais uma camada do tempo a que o bem está submetido.

Cada detalhe, cada elemento, cada desenho novo que foi completando e complementando o edifício preexistente revela o respeito aos seus aspectos estéticos, históricos e memoriais. Ainda que, para preservar, precisemos esquecer ou cancelar determinados fatos, há de se ter o cuidado de fazer a escolha certa no limiar do tênue fio entre estar ou não estar dentro dos limites da preservação e do respeito aos principais princípios que direcionam a atuação nesse campo disciplinar.

Todo projeto de restauro, qualquer que seja sua dimensão, realiza-se por meio da complementação do antigo com o novo, mas muitas intervenções ocorrem de maneira arbitrária, sem respeitar aspectos estéticos e históricos intrínsecos ao bem, sem respeitar seus valores memoriais, descaracterizando a constituição física original da edificação, ressaltando o novo em detrimento do antigo.

Não existe uma receita mágica, mas existem critérios, preceitos e normativas que vêm sendo debatidos há mais de um século e foram consolidados com o principal documento de orientação, que é Carta de Veneza.

Porém, existe uma grande dificuldade em incluir a arquitetura nessas orientações devido ao seu caráter de abrigo e função para a atividade humana. O edifício, diferentemente de uma pintura ou de uma escultura, em geral, foi concebido para um determinado tipo de público a partir de uso e fluxos preestabelecidos. 
Quando retomamos o art. 9 da Carta de Veneza, percebemos que pelos menos três dos cinco princípios basilares estão nele expressos: autenticidade ("respeito ao material original e aos documentos autênticos"); mínima intervenção (a restauração "tem por objetivo conservar") e distinguibilidade ("todo trabalho complementar indispensável [...] deverá ostentar a marca do nosso tempo"), princípios estes também preconizados por Cesare Brandi ${ }^{30}$.

Nas obras estudadas em cada uma das tendências notamos que a distinguibilidade é perseguida pelos arquitetos como forma de contrastar a sua arquitetura com o monumento do passado e como modo de registrar a sua marca. Em muitos casos, esse confronto entre as duas épocas, do ponto de vista metodológico, tem um resultado negativo na obra final, pois é promovido pelo exagero ou excesso em relação ao novo e fruto da falta de diálogo entre as diferentes arquiteturas de diferentes épocas.

Quando isso acontece, há um problema de percepção do tempo histórico do monumento e de suas qualidades estéticas, deixando em evidência o protagonismo do novo. O novo deve ser colocado a serviço do antigo como continuidade de sua história, para valorizar e explicar o monumento, e não o contrário.

Os casos citados estão em constante diálogo com o campo, ora se aproximando das indicações basilares do restauro, ora apresentando problemas de materialização da teoria na prática.

O "Completamento" segue a mesma linha do "Repristino", porém embasando sua intervenção em um projeto inacabado. Inacabado em um tempo diferente do momento em que se intervém, buscando impor ao monumento uma camada de tempo não condizente com a continuidade de sua vida útil, pois o projeto de intervenção é o projeto original do monumento inacabado executado em tempo passado e com características não condizentes com o tempo presente. Na "Apropriação", o passado é esquecido, pois o projeto contemporâneo é o protagonista da intervenção. Qualquer postura ou escolha é feita para o projeto do novo, aquilo que ficará para o

30. "a restauração deve visar o restabelecimento da unidade potencial da obra de arte, desde que isso seja possível sem cometer um falso artístico ou um falso histórico, e sem cancelar nenhum traço da passagem da obra de arte no tempo" (mínima intervenção e autenticidade); "a integração deverá ser sempre e facilmente reconhecível" (distinguibilidade); "qualquer intervenção de restauro não torne impossível mas, antes, facilite as eventuais intervenções futuras" (reversibilidade). BRANDI, Cesare. Op. cit, p. 33, 47 e 48. 
futuro e a preexistência perde sua identidade em uma atitude de posse do projeto do novo em relação ao existente.

Essas três tendências são representadas por intervenções em monumentos com pouco ou nenhum vínculo simbólico com o material antigo e não podem ser reconhecidas como restauro, ou seja, a transmissão do monumento às gerações futuras através da revelação de seus valores, conceito preliminar da restauração, não é alcançada pela predominância do novo na "Apropriação", pela promoção de um falso histórico no "Repristino", e pela equivocada continuidade do tempo no "Completamento".

Outras três tendências - "Diferenciação", "Reinterpretação" "Autonomia" - dialogam com o campo e procuram adequar-se mediante as aspirações dos autores e a finalidade da intervenção.

O grupo formado por $80 \%$ das intervenções, que caracterizam as tendências “Diferenciação", "Reinterpretação", "Autonomia”, "Apropriação", "Repristino" e "Completamento", engloba a maioria das obras analisadas, agrupadas principalmente na tendência da "Diferenciação", e demonstram que o fenômeno dos projetos das intervenções em monumentos arquitetônicos no Brasil caminha para a prática em que a experimentação é escolhida em prejuízo do juízo crítico dos valores impregnados no monumento.

Esse resultado é conduzido por uma somatória de fatores, entre eles: a vontade de impelir o usuário do monumento a novas experiências, a destinação de uso e todos os atributos a ela atrelados que induzem as escolhas de projeto, as solicitações do cliente e a falta de corpo técnico especializado na área.

A dose de criatividade requerida para a atualização dos espaços ou mudanças de uso que se coloca em cada um dos monumentos nas tendências de "Conservação" e "Reintegração" é subsidiada pelas características da preexistência. A descoberta de seus valores originais mascarados pela ação do tempo e a revelação de seus traços mais particulares, que lhe conferiram a denominação de monumento, ficam evidentes na ação de intervenção na qual o novo é posto a serviço do antigo.

Essas duas tendências representam aproximadamente $20 \%$ da produção nacional de intervenção em monumentos. Seria o que corretamente poderíamos chamar de restauro no Brasil na atualidade. São intervenções que consideram as prescritivas do campo do restauro no processo de modificação de obras de valor histórico e artístico. 
As ações de restauro permitem uma maior ou menor facilidade de conservação do edifício preexistente, de seu uso e da manutenção deste uso. Algumas vezes, o monumento é destinado a uma atividade e, com o passar do tempo, esse uso não é mantido, havendo uma mudança de programa e uma nova adaptação; outras vezes, por falta de conservação, o monumento restaurado perde seu uso e retorna a um estado de abandono; também se identifica, por falta de controle dos órgãos de preservação, que após algum tempo, alguns edifícios restaurados passam por reformas conduzidas pelo próprio usuário do prédio, e inicia-se, assim, um ciclo vicioso de remoções e/ou acréscimos corrigidos anteriormente durante a intervenção.

Esse arcabouço - o das obras selecionadas - forneceu importantes esclarecimentos sobre os procedimentos de intervenção em edifícios históricos no Brasil, contribuindo para a definição de oito tendências interventivas nas questões de diálogo entre o antigo e o novo. Através do estudo, avaliando o respeito pelo monumento em sua conservação e a criatividade para projetar o novo, a maior parcela dos velhos patrimônios têm sido objeto de projetos que encontraram novas perspectivas de intervenções em que - apesar da intenção pela preservação do monumento -, as ações guiam-se mais pela dose de fantasia que pela mínima intervenção, ou seja, a presença do novo é a marca do nosso tempo, muitas vezes materializada sem o respeito pela preexistência.

Ao avaliar o campo disciplinar do restauro no Brasil em confronto com a produção prática, vemos que um número reduzido de intervenções é construído tendo como referência os pressupostos da Carta de Veneza, as referências internacionais e o debate atual. O protagonismo do monumento em uma ação de preservação e conservação tem caminhado para um papel de coadjuvante em práticas que procuram dissociar-se do peso que a palavra restauro porta, e, desse modo, justificar as ações cada vez mais distantes do campo - sem o correto juízo crítico, cada vez com menos limites em relação à aproximação antigo/novo e com um imenso predomínio da projetação do novo sobre o antigo. 


\section{REFERÊNCIAS}

BONELLI, Renato. Il restauro architettonico. In: BRANDI, Cesare, et. al. Voce restauro. In: Enciclopedia Universale dell'Arte, v. XI, col. 322 e ss. Venezia-Roma, 1963.

CARBONARA, Giovanni. Architettura e restauro oggi a confronto. Palladio, Roma, n. 35, p.99-128, 2005.

CARBONARA, Giovanni. Architettura d'oggi e restauro: un confronto antico-nuovo. Torino: UTET Scienze Tecniche, 2011.

CASIELLO, Stella (a cura di). Restauro. Criteri, metodi, esperienze. Napoli: Electa Napoli, 1990.

CHOAY, Françoise. Trad. Luciano Vieira Machado. A alegoria do patrimônio. São Paulo: Estação Liberdade / Ed. Unesp, 2001, p.208-211.

DE ANGELIS D’OSSAT, Guglielmo. Restauro: architettura sulle preesistenze diversamente valutate nel tempo. Palladio, Roma, terza serie, anno XXVII, fasc. 2, p. 54, 1978.

INSTITUTO DO PATRIMÔNIO HISTÓRICO E ARTÍSTICO NACIONAL. Cartas patrimoniais. 3. ed. rev. aum. Rio de Janeiro: Iphan, 2004

JEUDY, Henri-Pierre. Espelho das cidades. Rio de Janeiro: Casa da Palavra, 2005.

NAHAS, Patricia Viceconti Nahas. Antigo e novo nas intervenções em preexistências históricas: a experiência brasileira (1980-2010). 2015. Tese (Doutorado em Arquitetura e Urbanismo) Faculdade de Arquitetura e Urbanismo da Universidade de São Paulo, São Paulo, 2015.

RUSSO, Valentina. Giulio Carlo Argan. Restauro, critica, scienza. Firenze: Nardini Editore, 2009.

SERAFINI, Lucia. Sopra, accanto, con l'antico. Il destino della preesistenza nel restauro contemporaneo. In: FERLENGA, Allberto; VASSALLO, Eugenio; SCHELLINO, Francesca (org.). Antico e Nuovo. Architetture e Architettura. Atti del Convegno "Antico e Nuovo. Architetture e Architettura", Venezia 31 de marzo - 3 aprile 2004, 2 vol. Padova: II Poligrafo, 2007.

TORSELLO, Paolo (org.). Che cos'e il restauro? Nove studiosi a confronto. Venezia: Marsilio Editori, 2005 